\title{
Bioremediation and Bioprospecting of Cow Dung and Poultry Droppings Enriched with Sewage Water for Biogas Production
}

\author{
V. Jeyanthi Kumari $(i)$ \\ A.P.C. Mahalaxmi College for Women, Thoothukudi - 628 002, Tamil Nadu, India.
}

\begin{abstract}
In this study, the biogas was produced by the gradual replacement of cow dung using sewage water and poultry dropping. Cow dung replacement with sewage water showed high utility of the total solids than the control bioreactor. In control bioreactor the total solid reduction is ranged between $10 \%$ and $\mathbf{9 . 8 \%}$, whereas in the experimental bioreactor which contained the gradual replacement of cow dung with sewage water, the total solid degradation occurred from $10 \%$ to $6.1 \%$. The analysis of biogas production by gradual replacement of cow dung with poultry droppings and sewage water revealed the total solids degradation range from $7.2 \%$ to $6.7 \%$. Total solid level reduction is considered to be one of the important parameter for biogas production. Regarding the production of biogas, the gradual replacement of cow dung with sewage water experimental reactor gave more biogas (1421lit/kg of dry matter/day) when compare to the control bioreactor (1007lit/k g of dry matter/day). The maximum gas production also occurred at $80 \%$ replacement with sewage water. The gradual replacement of cow dung with poultry droppings supplemented with sewage water revealed the high gas production (1952lit/ $\mathrm{kg}$ of dry matter/day) than the cow dung replacement with sewage water and control bioreactors. During the gradual replacement of cow dung with poultry droppings and sewage water concluded that there is an excellent biogas production in the $100 \%$ replacement of cow dung which in turn indicated that poultry droppings contains more total solid level which can be easily degraded by methanogenic organisms than in cow dung and sewage water can be a good nutrient source for biogas production.

Keywords: Total solid level, biogas production, methanogenic organisms, sewage water.
\end{abstract}

\footnotetext{
*Correspondence: jeyanthikumari@apcmcollege.ac.in

(Received: 22 November 2019; accepted: 24 December 2019)

Citation: V. Jeyanthi Kumari, Bioremediation and Bioprospecting of Cow Dung and Poultry Droppings Enriched with Sewage Water for Biogas Production, J Pure Appl Microbiol., 2019; 13(4):2507-2515. https://doi.org/10.22207/JPAM.13.4.66

(C) The Author(s) 2019. Open Access. This article is distributed under the terms of the Creative Commons Attribution 4.0 International License which permits unrestricted use, sharing, distribution, and reproduction in any medium, provided you give appropriate credit to the original author(s) and the source, provide a link to the Creative Commons license, and indicate if changes were made.
} 


\section{INTRODUCTION}

Agro-industrial residues, sewage water, large poultry and pig farms are often a major source of pollution in Asian countries ${ }^{1}$. The production, distribution, use, misuse, disposal of sewage water have polluted the environment that threatens the health of humans, livestock, wildlife and indeed whole ecosystems. At the same time these pollutants constitute a large potential for biogas production through anaerobic digestion ${ }^{2}$. The government, industry and the public have needed the effective alternatives to traditional physical and chemical methods for sewage management ${ }^{3}$.

In India, the biogas technology is based on cattle dung as the main feed stock ${ }^{4}$. Biogas has been produced traditionally from cattle dung but the reports about the need of cattle dung has been increased in years because of the reduced number of cattle ${ }^{5}$. The alternate substrates like excreta of sheep, goat, pig and other animal wastes both in combination with cattle dung and alone are possible to produce biogas ${ }^{6,7}$.

The raising cost and shortage of conventional fuel have generated renewed interest in producing methane from organic matter through anaerobic digestion ${ }^{8}$. The production of energy from alternative sources becomes not only more desirable but economically more feasible ${ }^{9,10}$. Biogas is one of the promising sources of alternative energy and the biogas technology of modern plant produces clean renewable with nutrient rich digested slurry ${ }^{11}$.

Technologies for treating farm wastes along with sewage polluted environments have been a major concern over the last couple of decades ${ }^{12}$. Research on anaerobic degradation of cellulosic wastes of cattle dung for enhanced biogas and ethanol production has shown the degrading ability of rumen microorganisms in biogas production ${ }^{13,14}$. The successive biogas production occurred when poultry droppings, parthenium and eucalyptus leaves with donkey dung combination ${ }^{15}$.

The temperature has a significant influence on methanogenic bacterial activity, bioremediation and stabilization efficiency in biogas production ${ }^{16}$. The effect of temperature is independent of loading rate and retention time ${ }^{17}$. The methanogenic activity, anaerobic biodegradability and toxicity are key parameters in the design and operation of anaerobic bioreactor ${ }^{18,19}$. There was no significant inhibition of biogas production in the presence of salinity but this salinity along with ammonium nitrogen levels have an impact on biogas production ${ }^{20}$.

Chemical oxygen demand, dry solids, volatile fatty acids and reactor volume occupied by the feed material are the important parameters in the biogas production. Effective bio conversion of organic matter in anaerobic digester depends on a diverse microbial population ${ }^{21}$. The slurry from biogas plant after biogas production used as a nutrient source in agriculture ${ }^{22}$. The bio digested slurries of biogas plant used as carriers for the preparation of carrier based inoculums acclaimed to play a vital role in modern agriculture ${ }^{23,24}$. In this study, the sewage water which is consider to be the chief source of contamination used as supplementary feed and replacement source along with cow dung and poultry droppings for biogas production.

\section{MATERIALS AND METHODS Sample Collection}

The present work was carried out using sewage water of Sewage effluent Treatment Plant (STP) of A.P.C. Mahalaxmi College campus, Thoothukudi. This is used as supplement for the production of biogas. The sewage water for STP is directly collected from hostel septic tanks, old hostel, new hostel and mess.

\section{Characteristics of sewage water}

The following parameters were analyzed in sewage water both in control and experimental bioreactors. The Total Solids (TS), Volatile Fatty Acids (VFA) and Total Volatile Solids (TVS) were estimated as per the procedure given in MACs manual $(1988)^{25}$.

\section{Bioreactor and loading Mode}

In this experiment KVIC (Kadhi Village Industries Commission) model anaerobic bioreactors were used for biomethanation process. Semi continuous process was followed for biogas production. Anaerobic bioreactors were used. The total capacity of a bioreactor is 46 liters. Cow dung and poultry droppings were used as substrates. For experimental purpose these substrates were supplemented with sewage water and the biogas production was done in a separate 
manner. The digesters were daily charged by these substrates for their stabilization. The experiment was carried out for the period of nearly 250 days continuously.

(i) In the first part of work, the control bioreactor was loaded with cow dung and ordinary water and the experimental bioreactor was loaded with cow dung supplemented with sewage water. The Retention Period (RT) for30days was maintained. After 30 days the gas output was measured by water replacement method ${ }^{26}$.

(ii) In the second part of work, the cow dung amount was gradually reduced by sewage water in the order of $20 \%, 40 \%, 60 \%$, $80 \%$ and $100 \%$. Total Solid (TS) concentration was maintained at $10 \%$ level. The gas output was measured by water replacement method.

(iii) Another set of experiment setup was carried out in the above said same manner but the cow dung was replaced in the order of $20 \%, 40 \%$, $60 \%, 80 \%$ and $100 \%$ level by poultry droppings with sewage water in the interval of 15 days. The sewage water level was maintained constantly. Here also the gas output was measured by water replacement method.

Table 1. Characteristic features of sewage water

\begin{tabular}{lccccc}
\hline TS(\%) & TVS(\%) & $\mathrm{N}(\%)$ & $\mathrm{P}(\%)$ & $\mathrm{K}(\%)$ & $\mathrm{C}(\%)$ \\
\hline $9.360 \pm 3.207$ & $60.290 \pm 2.472$ & $1.12 \pm 2.039$ & $0.32 \pm 1.074$ & $0.28 \pm 1.937$ & $28.2 \pm 3.008$ \\
\hline
\end{tabular}

Table 2. Total Solids (TS), Total Volatile Solids (TVS) and Volatile Fatty Acids (VFA) in control bioreactor

\begin{tabular}{|c|c|c|c|c|c|}
\hline \multirow{2}{*}{$\begin{array}{l}\text { No of } \\
\text { days }\end{array}$} & \multicolumn{2}{|c|}{$\mathrm{TS}(\%)$} & \multicolumn{2}{|c|}{ TVS(\%) } & \multirow[t]{2}{*}{ VFA(\%) } \\
\hline & Initial & $\begin{array}{l}\text { Every } 15 \text { days } \\
\text { interval }\end{array}$ & Initial & $\begin{array}{l}\text { Every } 15 \text { days } \\
\text { interval }\end{array}$ & \\
\hline Oday & $10.0 \pm 2.516$ & $7.6 \pm 1.835$ & $60.1 \pm 0.311$ & $62.2 \pm 1.997$ & $42.0 \pm 0.057$ \\
\hline $15^{\text {th }}$ day & $10.0 \pm 1.732$ & $7.9 \pm 1.646$ & $60.3 \pm 0.352$ & $64.2 \pm 0.900$ & $44.0 \pm 0.132$ \\
\hline $30^{\text {th }}$ day & $9.8 \pm 1.250$ & $7.6 \pm 2.657$ & $61.7 \pm 0.702$ & $66.2 \pm 0.950$ & $40.0 \pm 0.374$ \\
\hline $45^{\text {th }}$ day & $9.4 \pm 1.692$ & $7.6 \pm 1.662$ & $60.7 \pm 0.680$ & $64.8 \pm 1.193$ & $43.0 \pm 0.497$ \\
\hline $60^{\text {th }}$ day & $9.6 \pm 1.587$ & $7.8 \pm 1.743$ & $59.5 \pm 0.789$ & $62.4 \pm 0.680$ & $40.0 \pm 1.647$ \\
\hline $75^{\text {th }}$ day & $9.4 \pm 2.285$ & $6.6 \pm 0.208$ & $60.3 \pm 1.200$ & $63.8 \pm 2.066$ & $40.0 \pm 0.923$ \\
\hline $90^{\text {th }}$ day & $9.8 \pm 0.513$ & $6.4 \pm 0.351$ & $61.4 \pm 0.808$ & $64.2 \pm 1.153$ & $42.0 \pm 0.947$ \\
\hline
\end{tabular}

Values in Mean \pm Standard Deviation.

Table 3. Total Solids (TS),Total Volatile Solids(TVS) and Volatile Fatty Acids(VFA) in Experimental bioreactor(cow dung replacement with sewage water)

\begin{tabular}{|c|c|c|c|c|c|c|}
\hline \multirow{2}{*}{$\begin{array}{l}\text { No of } \\
\text { days }\end{array}$} & \multirow{2}{*}{$\begin{array}{l}\text { Amount of cow } \\
\text { dung replacement } \\
\text { with sewage water }\end{array}$} & \multicolumn{2}{|c|}{ TS (\%) } & \multicolumn{2}{|c|}{ TVS (\%) } & \multirow[t]{2}{*}{ VFA (\%) } \\
\hline & & Initial & $\begin{array}{c}\text { Every } 15 \text { days } \\
\text { interval }\end{array}$ & Initial & $\begin{array}{c}\text { Every } 15 \text { days } \\
\text { interval }\end{array}$ & \\
\hline Oday & $0 \%$ & $10.0 \pm 0.100$ & $6.3 \pm 1.053$ & $57.4 \pm 0.585$ & $65.8 \pm 1.504$ & $52.0 \pm 1.230$ \\
\hline $15^{\text {th }}$ day & $20 \%$ & $9.8 \pm 0.305$ & $6.6 \pm 0.608$ & $58.9 \pm 1.792$ & $66.2 \pm 1.150$ & $50.0 \pm 0.870$ \\
\hline $30^{\text {th }}$ day & $40 \%$ & $9.4 \pm 0.493$ & $6.9 \pm 0.550$ & $57.3 \pm 0.642$ & $66.8 \pm 2.954$ & $58.0 \pm 0.043$ \\
\hline $45^{\text {th }}$ day & $60 \%$ & $9.0 \pm 0.110$ & $6.1 \pm 0.150$ & $56.9 \pm 2.668$ & $64.9 \pm 1.616$ & $48.0 \pm 0.032$ \\
\hline $60^{\text {th }}$ day & $80 \%$ & $8.8 \pm 0.152$ & $6.8 \pm 0.519$ & $61.9 \pm 2.193$ & $72.8 \pm 1.101$ & $48.0 \pm 0.743$ \\
\hline $75^{\text {th }}$ day & $100 \%$ & $8.4 \pm 0.757$ & $7.2 \pm 1.106$ & $59.6 \pm 1.817$ & $68.2 \pm 5.466$ & $46.0 \pm 1.687$ \\
\hline $90^{\text {th }}$ day & $100 \%$ & $8.1 \pm 1.156$ & $7.1 \pm 0.251$ & $59.5 \pm 2.569$ & $68.8 \pm 6.086$ & $52.0 \pm 1.1043$ \\
\hline
\end{tabular}

Values in Mean \pm Standard Deviation. 


\section{Characteristics of outlet slurry}

The parameter analyses of outlet slurry were also done. The important parameters, $\mathrm{pH}$ and temperature were analyzed routinely both in control and experimental bioreactor. The temperature was ranged between $36^{\circ} \mathrm{C}$ to $38^{\circ} \mathrm{C}$ throughout the experimental period.

\section{Statistical analysis}

The characteristic feature of sewage water (Table 1), Total solids (TS), Total Volatile Solids (TVS) and Volatile Fatty Acids (VFA) in control bioreactor (Table 2) and experimental bioreactor of cow dung replaced with sewage water (Table 3) and all the experimental data were calculated by the average (mean) and standard deviation and given in the table as mean $\pm S D$ by using Microsoft Excel. Then the values were tested by ANOVA (analysis of variance) which revealed that there is a significant difference between the control and experimental bioreactor in gradual replacement of cow dung with sewage water (Table 4). The Student's ' $t$ ' test to explain the impact and individual analysis of TS, TVS \& VFA for the biogas production in the case of gradual cow dung replacement with sewage water (Table 5). The observed values of temperature and $\mathrm{pH}$ of both control and experimental bioreactors
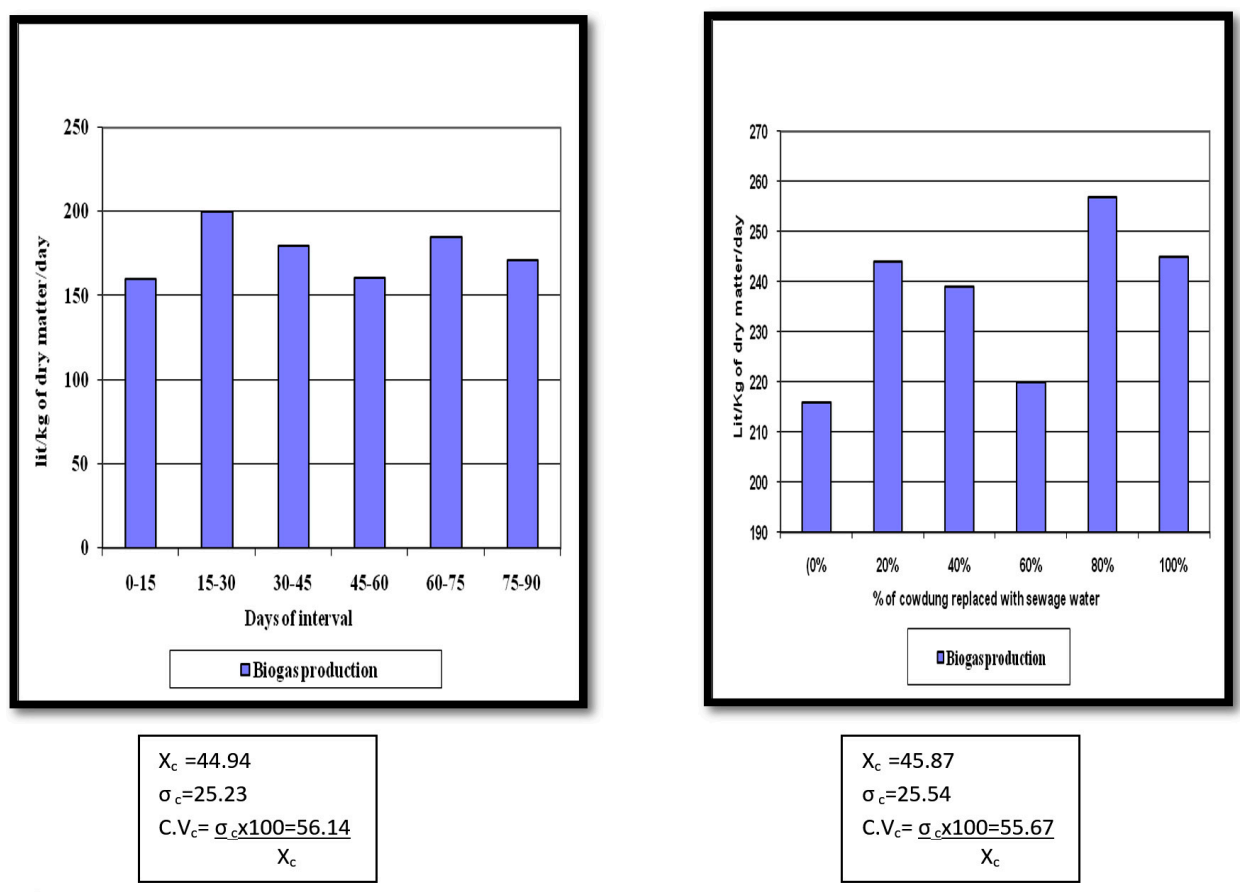

Fig. 1. Biogas production in control and experimental bioreactor (cow dung replaced wit sewage water)

Table 4. Analysis of varience (ANOVA) for the production of biogas between control and experimental bioreactor

\begin{tabular}{lcccccc}
\hline $\begin{array}{l}\text { Sources of } \\
\text { Variation }\end{array}$ & $\begin{array}{c}\text { Degrees of } \\
\text { freedom }\end{array}$ & $\begin{array}{c}\text { Sum of } \\
\text { squares }(\mathrm{x})\end{array}$ & $\begin{array}{c}\text { sum of } \\
\text { squares(y) }\end{array}$ & $\begin{array}{c}\text { Mean sum of } \\
\text { squares(x) }\end{array}$ & $\begin{array}{c}\text { Mean sum of } \\
\text { squares(y) }\end{array}$ & $\begin{array}{c}\text { Table value } \\
\text { of } \mathrm{F}\end{array}$ \\
\hline $\begin{array}{l}\text { Between } \\
\begin{array}{l}\text { Means } \\
\text { Between } \\
\text { products }\end{array}\end{array}$ & 2 & 17016.28 & 19269.21 & 8508.14 & 9634.61 & 3.55 \\
\begin{tabular}{l} 
Total \\
\hline
\end{tabular} & 18 & 13.55 & 42.96 & 0.75 & 2.39 & \\
\hline
\end{tabular}

Calculated value of $\mathrm{F}$ for $\mathrm{x}$ and $\mathrm{y}$ are greater than that of the table value of $\mathrm{F}$ for $(2,18)$ degrees of freedom. There is a significant difference between the control and the experiment. Based on that the further analysis was worked out for the same separately by using student 's t-test. 
which included the gradual replacement of cow dung with sewage water and gradual replacement of cow dung with poultry droppings and sewage water (Table 6) were recorded. Analysis of variance (ANOVA) for the production of biogas between control and experimental bioreactor of cow dung replacement with poultry droppings and sewage water is incorporated in Table 7. In Table 8, Student's " $\mathrm{t}$ " test analysis of TS, TVS\&VFA for biogas production by gradual reduction of cow dung supplemented with poultry droppings with sewage water was recorded and it revealed that they have very significant effect on producing TS, TVS and VFA. The Coefficient of variance analysis report revealed that experimental bioreactor is producing consistent biogas in the both experimental trials.

\section{RESULTS}

The study on the replacement of cow dung with sewage water showed high utility of the total solids from its initial level than the control bioreactor (Table 2 \& 3). In the experimental bioreactor the total solid degradation occurred from $10 \%$ to $6.1 \%$. From this it was observed that there was a significant gradual solid reduction in experimental bioreactor when compared to control.

The analysis of biogas production by gradual replacement of cow dung with poultry droppings and sewage water revealed that the total solids ranged between $7.2 \%$ and $6.7 \%$. This indicated that there was a significant solid reduction in experimental bioreactor when compare to control. The utility of solids by microbes in turn indicated the high productivity of biogas. Also high utility of total volatile solids, volatile fatty acids were observed in both experimental bioreactors compared to the control bioreactor respectively. Throughout the experimental period the $\mathrm{pH}$ ranged between 7.0 and 7.3. The temperature changes both in control and experimental bioreactors were observed between $36^{\circ} \mathrm{C}$ and $38^{\circ} \mathrm{C}$ respectively (Table 6).

The results revealed that the cow dung replaced with sewage water (1421lit/Kg of dry matter/day) gave more biogas production when compared to control bioreactor (1007lit/Kg of

Table 5. Student's " $\mathrm{t}$ " test analysis of TS, TVS \& VFA for biogas production by gradual reduction of cowdung supplemented with sewage water

$\mathrm{Ho}$ : There is significant difference between the production of TS, TVS and VFA in the control and in the experiment

\begin{tabular}{|c|c|c|c|c|c|c|}
\hline \multirow[t]{2}{*}{$\begin{array}{l}\text { No of } \\
\text { days }\end{array}$} & \multicolumn{2}{|c|}{$\begin{array}{c}{ }^{*} \text { Total solids } \\
\text { (\%TS) }\end{array}$} & \multicolumn{2}{|c|}{$\begin{array}{l}\text { *Total Volatile } \\
\text { Solids (\%TVS) }\end{array}$} & \multicolumn{2}{|c|}{$\begin{array}{l}\text { Volatile Fatty } \\
\text { Acids(\%VFA) }\end{array}$} \\
\hline & Control & Experimental & Control & Experimental & Control & Experimental \\
\hline 0 & 7.6 & 6.3 & 62.2 & 65.8 & 42.0 & 52.0 \\
\hline 15 & 7.9 & 6.6 & 64.2 & 66.2 & 44.0 & 50.0 \\
\hline 30 & 7.6 & 6.9 & 66.2 & 66.8 & 40.0 & 58.0 \\
\hline 45 & 7.6 & 6.1 & 64.8 & 64.9 & 43.0 & 48.0 \\
\hline 60 & 7.8 & 6.8 & 62.4 & 72.4 & 40.0 & 48.0 \\
\hline 75 & 6.6 & 7.2 & 63.8 & 68.2 & 40.0 & 46.0 \\
\hline 90 & 6.4 & 7.1 & 64.2 & 68.8 & 42.0 & 52.0 \\
\hline Total & 51.5 & 47 & 447.8 & 473.5 & 291.0 & 354.0 \\
\hline Mean & 7.357 & 6.714 & 63.971 & 67.643 & 41.5714 & 50.5714 \\
\hline \multirow[t]{2}{*}{ Varience } & 0.2622 & 4.4459 & 911.905 & & & \\
\hline & & & & \multicolumn{3}{|c|}{$t=2.179$} \\
\hline $\begin{array}{l}\text { Standard } \\
\text { deviation }\end{array}$ & \multicolumn{2}{|c|}{0.512} & \multicolumn{2}{|r|}{2.109} & \multicolumn{2}{|c|}{30.198} \\
\hline $\mathrm{T}$ & \multicolumn{2}{|c|}{$t=2.347$} & \multicolumn{2}{|r|}{$t=3.258$} & \multicolumn{2}{|r|}{$t=5.576$} \\
\hline
\end{tabular}

Table value of $t$ at $5 \%$ level of significance; Degrees of freedom $=12$;

*There is a significant difference between the control and experimental bioreactor $(p<0.05)$. Therefore the amount of cow dung replacement with sewage water has a very significant effect on producing total solids, total volatile solids and volatile fatty acids. 
dry matter/ day) (Fig. 1) and the maximum gas production was observed during $80 \%$ replacement. The maximum biogas production also occurred in that particular level. During $100 \%$ replacement, the amount of biogas production becomes lower which in turn indicated that the importance of organic rigid supportiveness and methanogenesis in the biogas production.

In the replacement of cow dung with poultry droppings supplemented with sewage water work also gave high gas production (1952lit/Kg of dry matter/day) than the control bioreactor (1007lit/Kg of dry matter /day) (Fig. 2). And this is concluded that there is an excellent biogas production biogas production in the $100 \%$ replacement of cow dung which in turn indicated that poultry droppings contains more total solid level which can be easily degraded by methanogenic organisms and sewage water can be a good nutrient source for biogas production.
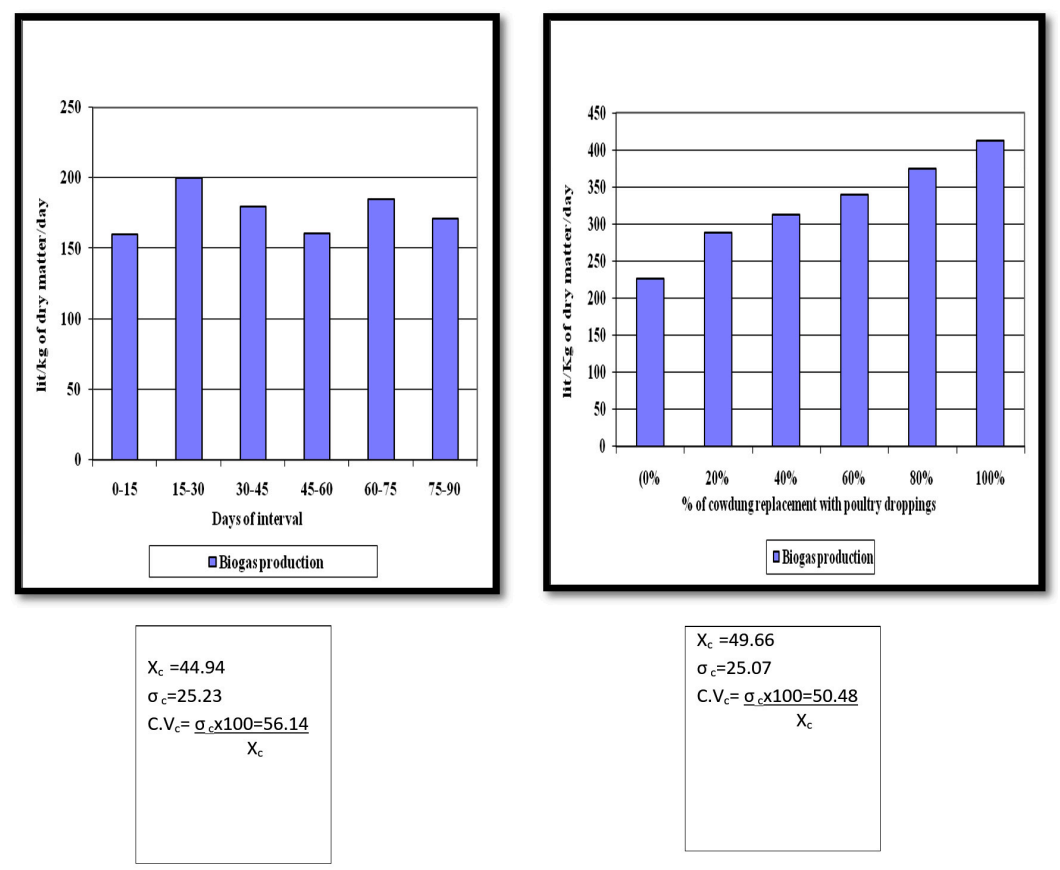

Fig. 2. Biogas production in control and experimental bioreactor (Cow dung replacement with poultry droppings and sewage water)

Table 6. Temperature and $\mathrm{pH}$ both in control and Experimental bioreactor

\begin{tabular}{|c|c|c|c|c|c|c|c|c|}
\hline \multirow{2}{*}{$\begin{array}{l}\text { Days } \\
\text { of } \\
\text { Days }\end{array}$} & \multicolumn{2}{|c|}{$\begin{array}{l}\text { Control } \\
\text { bioreactor }\end{array}$} & \multicolumn{2}{|c|}{$\begin{array}{c}\text { Experimental } \\
\text { bioreactor }\end{array}$} & \multirow{2}{*}{$\begin{array}{l}\text { Amount of } \\
\text { cow dung } \\
\text { replacement with } \\
\text { sewage water }\end{array}$} & \multicolumn{2}{|c|}{$\begin{array}{c}\text { Experimental } \\
\text { bioreactor }\end{array}$} & \multirow{2}{*}{$\begin{array}{l}\text { Amount of } \\
\text { cow dung } \\
\text { replacement with } \\
\text { poultry droppings }\end{array}$} \\
\hline & Temp. $\left(\mathrm{C}^{\circ}\right)$ & $\mathrm{pH}$ & Temp. $\left(C^{\circ}\right)$ & $\mathrm{pH}$ & & Temp. $\left(\mathrm{C}^{\circ}\right)$ & $\mathrm{pH}$ & \\
\hline 0 & 37 & 7.2 & 37 & 7.0 & $0 \%$ & 36 & 7.1 & $0 \%$ \\
\hline 15 & 38 & 7.2 & 38 & 7.2 & $20 \%$ & 37 & 7.4 & $20 \%$ \\
\hline 30 & 37 & 7.3 & 37 & 7.0 & $40 \%$ & 37 & 7.3 & $40 \%$ \\
\hline 45 & 37 & 7.1 & 37 & 7.2 & $60 \%$ & 38 & 7.5 & $60 \%$ \\
\hline 60 & 37 & 7.3 & 37 & 7.2 & $80 \%$ & 37 & 7.4 & $80 \%$ \\
\hline 75 & 36 & 7.2 & 36 & 7.2 & $100 \%$ & 38 & 7.6 & $100 \%$ \\
\hline 90 & 37 & 7.2 & 37 & 7.0 & $100 \%$ & 38 & 7.7 & $100 \%$ \\
\hline
\end{tabular}

Mean \pm SD $36 \pm 2.1^{\circ} \mathrm{C}$ for temperature and $7.2 \pm 0.2$ forpH.

Journal of Pure and Applied Microbiology 


\section{DISCUSSION}

The experiment bioreactors produced more biogas than the control. The gradual replacement of cow dung with sewage water gave maximum gas production at $80 \%$ replacement. There are a large number of parameters which affect the net energy output from a digester. Retention time will have an effect on the final gas production as well as the total and volatile solids in the feed materials ${ }^{27-29}$. In the present work the total solids ranged between $6.4 \%$ and $7.9 \%$ in control and between $6.1 \%$ and $7.2 \%$ in experimental bioreactor. The total solids value would be about $4 \%$ and do not exceed about $9 \%{ }^{30}$.

The volatile solids do not exceed above $90 \%$ or drop below $40 \%$ and $73 \%$ could be chosen as a reasonable value. In the present study, the maximum volatile solids were $72.8 \%$, it was observed in $80 \%$ replacement of cow dung with sewage water which gave more gas

Table 7. Analysis of varience (ANOVA) for the production of biogas between control and experimental bioreactor

\begin{tabular}{lcccccc}
\hline $\begin{array}{l}\text { Sources of } \\
\text { Variation }\end{array}$ & $\begin{array}{c}\text { Degrees of } \\
\text { freedom }\end{array}$ & $\begin{array}{c}\text { Sum of } \\
\text { squares(x) }\end{array}$ & $\begin{array}{c}\text { sum of } \\
\text { squares(y) }\end{array}$ & $\begin{array}{c}\text { Mean sum of } \\
\text { squares(x) }\end{array}$ & $\begin{array}{c}\text { Mean sum of } \\
\text { squares(y) }\end{array}$ & $\begin{array}{c}\text { Table value } \\
\text { of } F\end{array}$ \\
\hline $\begin{array}{l}\text { Between } \\
\text { Means }\end{array}$ & 2 & 17016.28 & 19269.21 & 8508.14 & 9634.61 & 3.55 \\
$\begin{array}{l}\text { Between } \\
\text { products }\end{array}$ & 18 & 13.55 & 42.96 & 0.75 & 2.39 & \\
\begin{tabular}{l} 
Total \\
\hline
\end{tabular} & 20 & & & & & \\
\hline
\end{tabular}

Calculated value of $\mathrm{F}$ for $\mathrm{x}$ and $\mathrm{y}$ are greater than that of the table value of $\mathrm{F}$ for $(2,18)$ degrees of freedom. There is a significant difference between the control and the experiment. Based on that the further analysis was worked out for the same separately by using student 's t-test.

Table 8. Student's " $t$ " test analysis of TS,TVS\&VFA for biogas production by gradual reduction of cowdung supplemented with poltry droppings with sewage water

Ho: There is significant difference between the production of TS,TVS and VFA in the control and in the experiment

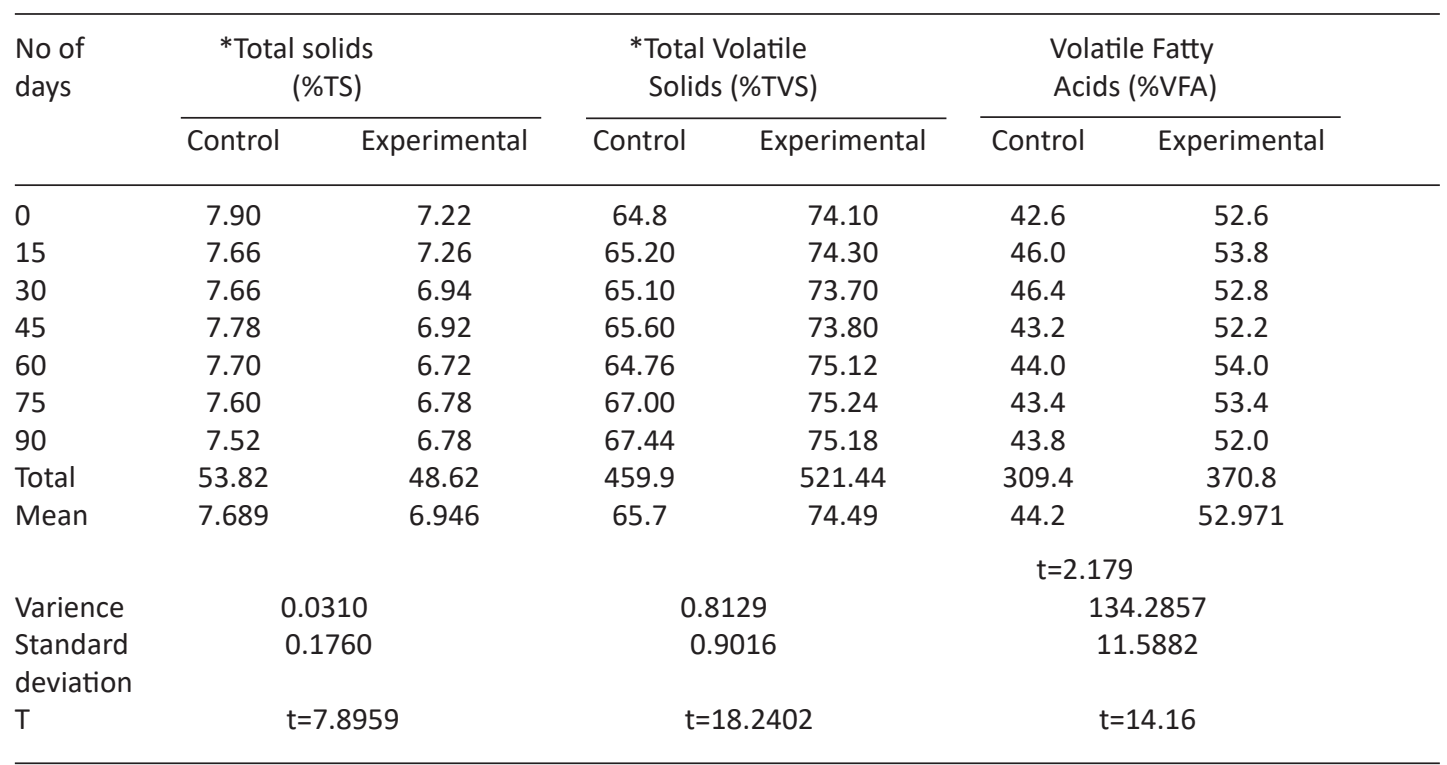

Table value of $t$ at $5 \%$ level of significance; Degrees of freedom $=12$;

*There is a significant difference between the control and experimental bioreactor $(p<0.05)$. Therefore the amount of cow dung replacement with sewage water has a very significant effect on producing total solids, total volatile solids and volatile fatty acids. 
production than other reduction concentration. The influence of temperature on the methanogenic bacterial activity, which inhibit the biodegradation and stabilization efficiency of substrates in bioreactor $^{31}$. In the present work also the mesophilic temperature was provided through out the experimental period and optimum gas yield was also obtained from this temperature.

The temperature fluctuation showed that the bio gas production almost stop and total VFA, such as acetate and propionate are rapidly accumulated, accompanied by the fail in $\mathrm{pH}$. Temperature fall not only affected the methanogenesis but also the hydrolysis and acidification $^{32}$. The maximum gas production occurred in the study of the cattle waste when the total solids are completely degraded. It was true because in the present study, the maximum volatilization of total solid biodegradation occurred during $80 \%$ replacement of cow dung by sewage water.

Among the various levels of solid concentration, total solid at $8 \%$ registered a higher biogas production or productivity followed by total solid at $6 \%^{33}$. In the cow dung replacement with poultry droppings and sewage water study, the reduction of solid occurred up to $6.72 \%$ The gas production was found to be maximum in $100 \%$ replacement of cow dung with sewage water treated poultry droppings sample which was also in accordance the results of Bonmati et al.,(2001) $)^{34}$. Many series of experiments for biogas production using cattle, poultry and sewage sludge separately and combinations ${ }^{35}$. Like that in this work, cow dung mixed with poultry droppings supplemented with sewage water gave comparatively maximum biogas yield than control which was loaded with cow dung and ordinary water. Among the various physical parameters, $\mathrm{pH}$ is the one which highly influences the microbial activity ${ }^{36}$. The optimum $\mathrm{pH}$ for biomethanation ranged between 6.5 and 7.7. ${ }^{37}$ The results of the present finding of the experimental bioreactor also depicted the similar results with the maximum gas yield being around neutral pH (Table 8).

\section{CONCLUSIONS}

From this study it is well observed that the sewage water which is considered to be the chief source of contamination used as a source of nutrient along with cow dung and poultry droppings for biogas production. Because these animals excrete leads to many problems like odour nuisance, fly nuisance apart from causing serious problems like eutrophication. These substrates act as an alternative renewable energy sources for conventional energy and economically more feasible. After biogas production, the slurry from the biogas plant used as bioorganic fertilizer. Conclusively recycling of these waste materials is necessary to prevent pollution and to conserve natural resources.

\section{ACKNOWLEDGEMENT}

I would like to thank the Chairman, Director and Principal of APC Mahalaxmi College for women for providing facilities and their constant encouragement to carry out this research study.

\section{FUNDING}

None.

\section{DATA AVAILABILITY}

All datasets and statistical report analyses during this study are included in the manuscript.

\section{ETHICS STATEMENT}

This article does not contain any studies with human participants or animals.

\section{REFERENCES}

1. Natarajan, K., Subbulakshmi, S., Ramachandramoorthy, V. Microbial production of silver nanoparticles. Dig. Jour. Microbiol., 2010; 5: 135-140.

2. Salval, S. Clean-up biotechnologies for soils and aquifers. J. Wat. Poll. Cot. Fed., 2011; S37: 1741-1747.

3. Ozalp, G., Gomec, C.Y., Oztr, I., Gonldinc, S. Effect of high salinity on anaerobic treatment of low strength effluents.Water Sci. Technol., 2010; 48: 207-212. https://doi.org/10.2166/wst.2004.0842

4. Zeikus, J.G. The biology of methanogenic bacteria. Bacterial. Rev., 1977; 41: 514-541.

5. Masse, D.I., Croteau, F., Masse, I., Danesh, S. The effect of scale up on the digestion of swine manure slurry in psychrophilic anaerobic sequencing batch reactor. Trans ASAE., 2004; 47: 1367-1373. https:// doi.org/10.13031/2013.16541

6. Al Masri, M.R. Changes in the biogas production due to different ratios of some animal and agricultural wastes. Biores. Tech., 2001; 77: 97-100. https://doi. org/10.1016/S0960-8524(00)00117-6

7. Angelidaki, I., Elledaard, L., Ah ring, B.K., Applications of the anaerobic digestion process. Adv. Biochem. Eng. 
Biotechnol., 2003; 82: 1-33. https://doi.org/10.1007/3540-45838-7_1

8. Lopez, I., Passeggi, M., Borzacconi, L. Co-digestion of ruminal content and blood from slaughter house industries: influence of solid concentration and ammonium generation. Water Sci. Technol., 2006; 54: 231-236. https://doi.org/10.2166/wst.2006.510

9. Munoz, R., Guieyee. Algal-bacterial proceeds for the treatment of hazardous contaminants. Water Res., 2006; 40: 2799-815. https://doi.org/10.1016/j. watres.2006.06.011

10. Fdz-Polanco, F., Nieto, P., Perez Elviral, S., Vander zee, F.P., fdz-Polanc, M., Garcia, P.A. Automated equipment for anaerobic sludge parameters detwemination. Water Sci. Technol., 2005; 52: 479-485. https://doi. org/10.2166/wst.2005.0556

11. Hobson, P.N., Robertson, A.M., Mills, P.J. Anaerobic digestion of agricultural wastes. ARC Review, 1975; 1: 82-85.

12. Sri RamaJayam. S. Biogas potential of kitchen waste. J. Ecobiol., 2008; 22: 11-15.

13. Ananthakalaiselvi, A., Dharmalingam, C., Soaking/ Pelleting with botanicals as a cheap technology to improve germination and vigour of papaya seeds (Carica papaya). South Indian Hort., 1995; 46: 132-134.

14. Sharma, A., Comboj, N. rastagi, D.V., Dogra, R.C. Simple method to study nodule occupancy of Bradyrhizobium sp marked with gus A gene. Indian J. Microbiol., 1997; 37: 91-94.

15. Madhiazhagan, R., Prabhakaran, N.K., Venkatasamy, R., Chandrasekaran, C. Response of cultivar to organic and inorganic fertilizer in ground not. Madras Agric. J., 2001; 88: 742-744.

16. Barbar, R.E. Current costs of solar powdered organic rankine cycle engines. Solar Energy, 1978; 20: 1-5. https://doi.org/10.1016/0038-092X(78)90133-0

17. Kannan,N., Guruswamy, T., Kumar, V., Design, Development and Evaluation of Biogas plant using Donkey-dung and selected biomaterial as Feedstock. (IECI) Journal AG., 2003; 84: 17-23.

18. Fisher, R.J. Anaerobic digestion of Swine manure at various Influent Solids concentration. Agric. Wastes, 1984; 11: 157-166. https://doi.org/10.1016/01414607(84)90042-8

19. Jungersen, G., Kivaisi Rubinda mayugi, A. BiogasBioenergy potential in East Africa.Proc. Workshop on Bioenergy from Sisal wastes. Silver Sands, Dar es Salaam. 1997; 22-23.

20. Kumar, S., Biswas, T.D.Biogas production from different animal excreta. Indian J. Agric.Sci., 1982; 52: 513-520.

21. Zhang, J.S., Sun, K.W., Wu, M.C., Zhang, L. Influence of temperature on performance of anaerobic digestion of municipal solid wastes. J. Environ Sci., 2006; 18: 810-815.

22. Ranjana Bhatia, Rakesh Kumar, Manjula Vasudev, Baaljeet singh Saharan, Raj Kumar Bansal, Neeru Narula. Production of microbial inoculants: Comparision of liquid and charcoal based biofertilizers. Technology, 2008; 10: 91-96.

23. Van velson, A.F.M. Anaerobic digestion of piggery waste. The influence of detection of detevtion time and manure conservation. Neth. J. Agric. Sci., 1977; 25: 151-159.

24. Dinesh Kumar, Y.K., Vishwanath, A.P., Vithalnavi, C., Atheek, H.M., Rahaman, U.R., Anand, M.R. Influence of organic and chemical amendments on enzymatic activities during composting of organic residues. $J$. Ecobiol., 2008; 22: 25-28.

25. MACS. Microbiological aspects of anaerobic digestion. $2^{\text {nd }}$ edn., Maharastra Association for the cultivation of Science, Pune, India, 1988; 1-112.

26. Swaminathan, K.R., Vijayaraghavan, N.C., Ramasamy, K.Estimation of volatile fatty acids In: Biochemical and thermochemicai engineering for non conventionalenergy sources. Practical manual. (K.R. Swaminathan (ed.), Department of bioenergy, T.N.A.U. Coimbatore, Tamil nadu. 1982; pp.20.

27. Hobson, P.N., Shaw, B.G. Inhibition of methane production by methanobacterium formicicum. Water Res., 1976; 10: 849-852. https://doi.org/10.1016/0043$1354(76) 90018-X$

28. Kaul, S.N., Nandy, T., Trivedy, R.K. Methods of treatments In: Pollution control in distilleries. (S.N.Kaul(ed.), University press, Cambridge. 1990; 33-34.

29. Demirer, G.N., Duran, M., Erguder, T.H., Guven, E., Ugurlu, O., Yezel, U. Anaerobic treatability and biogas production potential studies of different agro-industrial waste water in Turkey. Biodegradation, 2000; 11: 401405. https://doi.org/10.1023/A:1011659705369

30. Wong-Chong, G.M. Dry anaerobic digestion In: Energy agriculture and waste management. (W.J. Jewell (ed.). Ann Arbor Sci., Ann. Arbor. Mich. 2000; 361.

31. Bal, A.S., Dhagat, N.N. Up flow anaerobic sludge blanket reactor-a review. Indian J. ERnviron. Health, 2001; 43: 1-82.

32. Wu, M.C., Sun, K.W. Effect of the temperature fluctuations performance of thermophilic anaerobic digestion for treating organic fractions of municipal solid wastes. Haun Jing Ke xue., 2006; 2794: 805-809.

33. Leelawati, R.K. Malik, Chayanika putatunda. Poultry manure enriched Biogas effluent slurry- a potential organic manure. Geobios., 2008; 35: 133-136.

34. Bonmati, A., Flotats, X., Mateu, L., Campos, E. Study of thermal hydrolysis as a pretreatment to mesophilic anaerobic digestion of pig slurry. Water Sci. Technol., 2001; 44: 109-116. https://doi.org/10.2166/ wst.2001.0193

35. Spencei, R.R. Enhancement of methane production in the anaerobic digestion of sewage sludge. Biotech and Bioeng., 1978; 257-261.

36. Hae, N.H., Park, S.C., Lee, J.S. Kang, H., Park, D.H. Single-stage anaerobic co digestion formixture wasteof simulatedKorean food wasteand water activated sludge. Appl. Biochem. Biotechnol., 2003; 105: 567579. https://doi.org/10.1007/978-1-4612-0057-4_47

37. Smith, P.S., Hungate, R.E. Isolation and characterization of Methanobacterium ruminatium. Nsp. J. Bacteriol., 1958; 75: 713-718. 